\title{
DEMAND AND TYPE OF CARE PROVIDED IN EMERGENCY SERVICES IN THE CITY OF FLORIANÓPOLIS, BRAZIL
}

\author{
Sonia da Silva Reis Cassettari ${ }^{1}$, Ana Lúcia Schaefer Ferreira de Mello ${ }^{2}$
}

\footnotetext{
${ }^{1}$ M.Sc. in Nursing. RN, City Health Department. Florianópolis, Santa Catarina, Brazil. E-mail: soninhareis@gmail.com

2 Ph.D. in Nursing. Professor, Department of Dentistry, Graduate Nursing Program and Graduate Dentistry Program, Universidade Federal de Santa Catarina. Florianópolis, Santa Catarina, Brazil. E-mail: alfm@terra.com.br
}

\begin{abstract}
Objective: this study's aim was to characterize the demand of patients and the type of care provided in 2013, in emergency services, in the city of Florianópolis, SC, Brazil.

Method: this is a descriptive and analytical study with a quantitative approach. Secondary data were collected from general and managerial reports provided by the information system used by the city's department of health.

Results: patients seek the emergency services nearest to their homes for situations not characterized as emergencies and that could be taken care of by primary health care units

Conclusion: most patients originate from the same health district in which the emergency service is located and their reasons for seeking care could not be characterized as urgent or emergency situations. There is a need to qualify primary health care as the coordinator of care and instruct the population regarding the role of each service in the network.
\end{abstract}

DESCRIPTORS: Health services. Health services needs and demand. Prehospital care Emergency medical services.

\section{DEMANDA E TIPO DE ATENDIMENTO REALIZADO EM UNIDADES DE PRONTO ATENDIMENTO DO MUNICÍPIO DE FLORIANÓPOLIS, BRASIL}

\section{RESUMO}

Objetivo: caracterizar a demanda de usuários e o tipo de atendimento realizado em Unidades de Pronto Atendimento do município de Florianópolis, Santa Catarina, Brasil, no ano de 2013.

Método: trata-se uma pesquisa descritiva e analítica com abordagem quantitativa. Foram coletados dados secundários, obtidos por meio de relatórios gerais e gerenciais do sistema de informação, utilizado pela Secretaria de Saúde da capital.

Resultados: constatou-se que os usuários utilizam a Unidade de Pronto Atendimento que está mais próxima de residência e que procuram o serviço por motivos não urgentes, que poderiam ser atendidos na atenção primária.

Conclusão: a maioria dos usuários era proveniente do mesmo distrito sanitário da unidade e os motivos dos atendimentos não eram, precisamente, caracterizados como urgência e emergência. Percebe-se a necessidade de qualificar a atenção primária como ordenadora do cuidado e orientar a população sobre quais as atribuições de cada ponto da rede.

DESCRITORES: Serviços de saúde. Necessidades e demandas de serviços de saúde. Assistência pré-hospitalar. Serviços médicos de emergência. 


\title{
DEMANDA Y TIPO DE ATENCIÓN REALIZADO EN UNIDADES DE EMERGENCIA DE LA MUNICIPALIDAD DE FLORIANÓPOLIS, BRASIL
}

\begin{abstract}
RESUMEN
Objetivo: caracterizar la demanda de usuarios y el tipo de atención en Unidades de Emergencias de la municipalidad de Florianópolis, Santa Catarina, Brasil, en el año 2013.

Método: investigación descriptiva y analítica con abordaje cuantitativo. Fueron recolectados datos secundarios, obtenidos a través de relatorías generales y gerenciales del sistema de información, utilizado por la Secretaría de Salud de la capital.

Resultados: Se constató que los usuarios utilizan la Unidad de Emergencia que está más próxima de la residencia y que procuran el servicio por motivos no urgentes, que podrían ser atendidos en la atención primaria.

Conclusión: la mayoría de usuarios era proveniente del mismo distrito sanitario de la unidad y los motivos de atendimientos no eran precisamente, caracterizados como de urgencia y emergencia. Se percibe la necesidad de calificar la atención primaria como ordenadora del cuidado y orientar a la población sobre cuáles son las atribuciones de cada punto de la red.

DESCRIPTORES: Servicios de salud. Necesidades y demandas de servicios de salud. Asistencia pre-hospitalaria. Servicios médicos de emergencias.
\end{abstract}

\section{INTRODUCTION}

From the perspective of the Health Care Network, the units implementing health actions and providing health services have the same relevance when it comes to achieving objectives that are common to the production of health in the population. The primary health care (PHC) service is supposed to be the main entrance door and channel of communication with all the remaining services that compose the network, whether it is at the secondary or tertiary level, which provide services with greater technological density. Each level, however, has its own responsibilities and specifications in the production of health care. ${ }^{1}$

PHC services have three key responsibilities: problem-solving capacity - solve more than $85 \%$ of health problems presented by the population; communication - establish communication with the remaining levels of care, being able to organize the flow and counter-flow of people at these levels; and accountability - being responsible for the health actions implemented in the territory under their coverage. There is no single configuration of the network at the secondary and tertiary levels capable of meeting the population's health needs. Hence, thematic networks are organized intending to meet all the population's health needs. Health care is structured into thematic networks, such as mental care networks; women and child care networks; and urgent and emergency networks, among others. ${ }^{1}$

Specifically, considerable advancements have been achieved in the Emergency Care Network within the Brazilian Public Health System (SUS). The National Policy of Emergency Care developed a regionalized and hierarchical network of integral care intended to meet urgent needs, regardless of the level of care, so that not only hospital emergency rooms are able to provide such care. ${ }^{2}$
The following services compose the Brazilian Emergency Care Network: Primary Health Care (PHC); SAMU (Mobile Emergency Service); SAMU Regulation Centers; Stabilization Room; Pre-hospital Service - UPAs (Emergency Care Units); Hospitals; Home Care; Health Promotion, Prevention and Surveillance of Diseases; and SUS National Health Force. ${ }^{3}$

In this context, the fixed pre-hospital service provided through UPAs is defined as the first care provided to patients in cases of acute conditions, trauma, or psychiatric disorders that may lead to death or result in sequelae, so that proper care is provided and/or transportation is arranged to another reference service linked to the State Emergency System, according to a regulated hierarchy, whenever necessary. ${ }^{4}$

Therefore, UPAs are relatively new components in the emergency care network and are defined as an intermediate structure between PHC services and the hospital network. UPAs' main functions are: to provide care to less complex urgent situations; functioning as a support network for the PHC service; provide care to the population during weekends and at night when PHC units are closed; reduce the demand on hospitals with a lower level of complexity; and communicate and cooperate with PHC, SAMU, hospital facilities, diagnostic and therapeutic support units, and other services through logical and effective reference and counter-reference flows organized by SAMU regulation centers, and regulatory complexes implemented in the region. ${ }^{3,5}$

The urgent care and emergency services in Brazil are currently facing problems of overcrowding due to the population having no regular access to the other levels of care. Factors such as a lack of beds in public hospitals and the population's increased longevity influence the overcrowding of 
urgent care and emergency services by those with chronic diseases. ${ }^{6}$

Therefore, UPAs end up providing care that is not within their scope and absorb patients who could be cared for by other services within the network. Numerous factors cause overcrowding of UPAs with patients who could have their health problems cared for in a PHC unit. Overcrowding takes time, human resources, equipment, and produces financial expenses, which could be directed to patients really facing an urgent or emergency situation. ${ }^{7}$

The questions resulting from the previous discussion include: what are the main reasons leading patients to seek care in a UPA? What are the main types of care provided by UPAs? Does this demand mostly involve urgent and emergency situations? What is the origin of patients seeking care in UPAs? Given this context, this study's aim was to characterize the demand of patients and type of care provided in UPAs, in 2013, in the city of Florianópolis, Brazil.

\section{METHOD}

This descriptive and analytical study presents a quantitative approach. The study was conducted in two UPAs located in Florianópolis, State of Santa Catarina, Brazil. The UPAs are open 24 hours and have operated for at least five years, according to the National Policy of Emergency Care and its subsequent amendments.

In 2013, Florianópolis had an estimated population of 453,285 inhabitants. ${ }^{8}$ It is geographically divided into five health districts, has 49 PHC units, four policlinics, two UPAs, four CAPS (Psychosocial Support Centers), two Dental Centers and four SAMU units under the city's management. The regulatory complex is part of SAMU, which is responsible for organizing the flow of urgent and emergency patients whenever they need to be transferred to another service within the healthcare network. Data from 2012 show that $92.85 \%$ of the population was covered by the Family Health Strategy.

The study was conducted in three stages. The first included collecting secondary data, obtained through general and managerial reports provided by Infosaúde, an information system used by all the health units in the city. Data for studies of this nature can be obtained and compiled using information available in the system. Analysis of demand and type of care using secondary data is relevant to providing information for planning, monitoring, and the (re)structuring of health services in a city.
The reports generated for later analysis included: quantitative reports of patients cared for by UPAs; origin of patients: classification of risk among adults in UPAs; reason for seeking care, according to the International Classification of Diseases (ICD); and type of care provided. General and managerial reports were collected from January to December 2013 in order to include 12 complete months and verify particularities of each season/period of the year. A total of 54 reports were generated in this period.

The second stage included cleaning data, organizing Excel® spreadsheets for better visualization and analysis; the database was organized into eight spreadsheets. The third stage included the analysis and description of data using descriptive statistics.

The Ethical Review Board at the Federal University of Santa Catarina approved the study in 2014 (No. 526.152). The UPAs where data were collected were identified as UPA A and UPA B to keep their identities confidential.

\section{RESULTS}

In 2013, UPAs A and B provided care to 413,248 patients, including children and adults. UPA A provided care to 188,766 individuals, while UPA B provided care to 224,482 individuals. These numbers include medical and nursing consultations, dental care, nursing procedures, and consultations with other workers with a college degree.

The origin of patients using UPAs follows the logic of geographical proximity; that is, the individuals seek UPAs nearest to their homes. They initially seek the UPA that is located within their Health District, and when this district does not have a UPA, they seek the one from the nearest health district. The results show that $70.53 \%$ of the patients cared for by UPA A live in the same health district in which the service is located, reinforcing the view that there is preference for seeking a unit near home. The patients from UPA B also sought care near home, as $81.37 \%$ of those seeking the unit lived in the same health district in which UPA B is located.

Table 1 shows that $96.31 \%$ of the patients cared for by UPA A in 2013 were from Florianópolis, while $3.67 \%$ were from other cities, states or countries. In regard to UPA B, 93.88\% of those cared for in 2013 were from Florianópolis and $6.10 \%$ were from other cities, states or countries. 
Table 1 - Patients cared for by UPAs A and B, according to locale of origin, Florianópolis, SC, Brazil, Jan to Dec 2013

\begin{tabular}{|c|c|c|c|c|c|}
\hline \multicolumn{3}{|c|}{ Pre-hospital service A } & \multicolumn{3}{|c|}{ Pre-hospital service B } \\
\hline Local of origin & No. of services & $\%$ accumulated & Local of origin & No. of services & $\begin{array}{c}\% \\
\text { accumulated }\end{array}$ \\
\hline $\begin{array}{l}\text { Same health district } \\
\text { as UPA A }\end{array}$ & 133.153 & 70.54 & $\begin{array}{l}\text { Same health district as } \\
\text { UPA B }\end{array}$ & 182.662 & 81.38 \\
\hline $\begin{array}{l}\text { Remaining health } \\
\text { districts in Flori- } \\
\text { anópolis }\end{array}$ & 48.676 & 25.79 & $\begin{array}{l}\text { Remaining health dis- } \\
\text { tricts in Florianópolis }\end{array}$ & 28.102 & 12.52 \\
\hline Santa Catarina & 3.610 & 1.91 & Santa Catarina & 2.672 & 1.19 \\
\hline Brazil & 2.625 & 1.39 & Brazil & 7.643 & 3.40 \\
\hline Abroad & 702 & 0.37 & Abroad & 3.403 & 1.51 \\
\hline Total & 188,766 & 100 & Total & 224,482 & 100 \\
\hline
\end{tabular}

Source: Infosaúde, 2013.

In 2013, a total of 143,464 patients were classified by UPAs in Florianópolis, based on a classification of risk. Note that only adult clinical patients go through risk classification that is established by a nurse. Surgical, pediatric, and dental patients go directly to the specialized consultation.

Table 2 presents the care provided to adults according to the classification established by a nurse.

Table 2 - Care provided to adults according to classification of risk established by UPA A and B Florianópolis, SC, Brazil. from Jan to Dec 2013

\begin{tabular}{lcc}
\hline \multicolumn{1}{c}{ UPA A and B classification of risk } & N. of care provided & $\%$ \\
\hline Outpatient care & 68,169 & 47.52 \\
Intercurrences & 63,259 & 44.10 \\
Urgent & 11,414 & 7.95 \\
Emergency & 622 & 0.43 \\
\hline Total & $\mathbf{1 4 3 , 4 6 4}$ & $\mathbf{1 0 0}$ \\
\hline
\end{tabular}

Source: Infosaúde, 2013.

The main reasons individuals seek medical care in these UPAs are presented in Table 3, which lists the ten most common ICD codes, in order, as recorded by the professionals from January to December 2013.

Table 3 - Reasons for seeking care in UPAs A and B in the city of Florianópolis from Jan to Dec 2013 according to International Classification of Diseases

\begin{tabular}{lcc}
\hline International Classification of Diseases & $\mathbf{n}$ & $\%$ \\
\hline General medical examination & 16,000 & 7.59 \\
Acute nasopharyngitis [common cold] & 9,051 & 4.30 \\
Acute tonsillitis, unspecified & 7,326 & 3.48
\end{tabular}


Acute upper respiratory infection, unspecified

General examination without complaint, suspected or reported diagnosis

Counseling, unspecified

Diarrhea and gastroenteritis of presumed infectious origin

Cough

Lower back pain

Nausea and vomiting

Others

Total

$$
6,069
$$

5,990

5,949

5,529

4,331

3,941

3,822

142,958

210,966
2.87

2.83

2.81

2.62

2.05

1.86

1.81

67.78

100

Source: Infosaúde, 2013.

Note that in 2013, a total of 210,966 ICD codes were recorded in the electronic medical files of the patients from the UPAs located in Florianópolis. Of these, an expressive number of patients were cared for and had recorded in their files the codes for General medical examination and General examination without complaint, suspected or reported diagnosis, so that a more detailed analysis of consultations could not be performed. For that reason, we cannot state with certainty that these consisted of outpatient care without urgency.

On the other hand, if we exclude General medical examination and General examination without complaint, suspected or reported diagnosis from Table 3, the remaining causes for patients to seek the UPAs are not characterized as an emergency or urgent situation namely, nasopharyngitis, tonsillitis, acute infection of the upper airways, counseling, diarrhea and gastroenteritis, cough, headache, backache, nausea and vomiting.

\section{DISCUSSION}

Ideally, contact with public health services should take place through PHC services implemented with the highest degree of decentralization and greatest dispersion, and mainly based on the geographical proximity to patients. ${ }^{9-10}$ In this way, UPAs represent an option for those using the public health system to access the services, mainly because they are the nearest to the patients' homes. Considering, however, that during the period of data collection more than $90 \%$ of the population had PHC available through health care units open during daytime hours, users were expected first to seek the PHC unit in the area of coverage. If that was not possible, another health unit could be accessed, adopting the same criterion of proximity, since any health unit belonging to the system is supposed to welcome and care for patients facing an urgent or emergency situation and transfer them to another service, if necessary. ${ }^{10-11}$

One systematic review seeking to understand the reasons leading the population to seek emergency services (e.g. ambulances) when people could have their needs met in a PHC unit, revealed that the individual characteristics of patients and those of their caregivers (health condition, perception regarding the condition's level of severity, feelings such as anxiety or loneliness), aspects related to the services' infrastructure and organization (the adoption of models based on PHC, but also the prior experiences of users and their levels of satisfaction), as well as social factors (demographic and socioeconomic factors and whether the individual has health insurance) are factors that influence an individual's decision to seek this type of service. ${ }^{12}$ In this sense, the authors state that considering the search for emergency services "inappropriate" to solve problems that could be solved in PHC units depends on the context and can be an innocuous approach when organizing health services. Hence, the focus of emergency services should be on strengthening screening strategies and classification of risk. ${ }^{12}$

The city under study has a specific protocol to classify risks, according to which cases considered to be an emergency should be immediately taken care of in the emergency room; cases considered to be urgent situations deserve attention and should be assessed by a physician within 30 minutes; cases classified as intercurrences are less severe urgent care situations and can be taken care of within 60 minutes; and finally, outpatient cases are not urgent and can wait more than 120 minutes or be referred to a reference health unit after first contact. ${ }^{13}$ Only $0.43 \%$ of the cases were classified as emergency and $7.95 \%$ were considered to be urgent matters, indicat- 
ing UPAs are not fulfilling their true mission, that of mainly providing care to urgent situations and emergencies, composing the emergency network, and rapidly and timely providing care to patients without losing sight of principles such as humanization and integral care. ${ }^{3}$

On the other hand, $44.09 \%$ of the patients were classified as intercurrences and $47.51 \%$ were considered to require outpatient care. That is, these individuals were not characterized as urgent cases and presented situations that could be solved within a PHC unit, in which longitudinal follow-up would be provided by these units' health workers.

PHC should be prepared to provide initial care in urgent situations through attentive listening and classification of risk. This way, users classified as requiring outpatient care should access the services through the main entrance of the healthcare network, following principles such as the establishment of bonds, continuity of care, integrality of care, accountability, universality, and humanization, so that patients would have their needs met according to this level's limitations. ${ }^{10}$ One intervention study conducted in the United States, the objective of which was to integrate patients cared for by emergency services into PHC services, identified the main barriers preventing patients from seeking PHC care as including a lack of transportation and difficulties in leaving children under someone's else responsibility. ${ }^{14}$

In England, fragmentation that still exists in the health system doubles the effort and difficulties patients have to face to go through the network efficiently. Additionally, the different names of services cause confusion, so patients do not have their needs met the first time because they do not go to the right place, consequently do not receive care from professionals with the right abilities in the first consultation. Evidence shows there are variations in England regarding how PHC services are accessed, consequently many patients demand urgent and emergency services to resolve cases that could be treated in PHC services. There are also differences in the way patients with chronic conditions are handled in PHC services, which contributes to a higher demand on emergency services. ${ }^{15}$

Studies indicate that the population seeks emergency services in situations that do not fit the description of emergencies because of a difficulty accessing other services in the network. The reasons for the difficulties include the PHC units' reduced working hours, which hinders the access of the working population, and the fact that UPAs have access to resources with greater technology so that patients do not have to commute to other services in the network..$^{14,16}$

Data collected from the reports provided by the Infosaúde system did not enable the researchers to assess the hours those patients classified as being intercurrences or outpatients were served. Identifying the times care was provided, whether patients visited the service at night or during weekends or holidays, would confirm whether UPAs serve as a backup for PHC services. If intercurrence occurs at night and the individual cannot wait until the next day, UPAs have the responsibility to cover for PHC units, especially at night, on holidays or weekends. ${ }^{4}$

Emergency services become the entrance door for numerous health problems. ${ }^{17}$ Analysis of the main services provided indicate that most are characterized as problems that could be addressed in a PHC unit, if principles concerning the reception of patients and providing humanized and integral care were applied. PHC has an essential role in the establishment of the healthcare network because it is close to the routines and lives of people. PHC teams can establish bonds with patients, take responsibilities, and develop collective actions to promote health and prevent diseases in a delimited area, and provide individual and family care, in addition to managing therapeutic regimes. ${ }^{18}$ It is worth noting that these times of distress are essential for the establishment and strengthening of bonds when they are responded to in a positive way. Patients usually seek a PHC unit because of its proximity or the bond established with a trusted professional; knowing a patient's history facilitates the identification of the problem and its solution on the part of the PHC professional. ${ }^{18}$

One intervention study conducted in Canada proposed a care model to individuals living in a long-term care facility, who very frequently demanded emergency services. The proposal was based on improved access and the continuity of PHC through the continuous presence of physicians focused on primary care, improved relational and information tools, as well as support provided by telephone on a permanent basis. The actions decreased the demand for emergency services by one third. ${ }^{19}$

Individuals seek urgent and emergency services for various reasons, among which are that these are "open-door" services with the possibility to provide a rapid response. For this reason, there is difficulty in changing this habit that is culturally rooted and based on strong beliefs. ${ }^{20}$ Many 
people have a distorted view of UPAs compared to PHC units, as they believe UPAs are faster and have greater problem-solving capacity given the fact they are equipped with greater technological density, with more resources such as equipment for performing exams, more medications and access to specialists. In most cases, patients seek emergency care, however, PHC units would have the tools necessary to provide integral and efficacious care, which would facilitate continuity through bonds established with the units' professionals. Therefore, it is necessary to strengthen guidance provided to the population, encouraging new habits concerning the search for health care services. ${ }^{14}$

PHC services are not less complex than services at the secondary and tertiary levels. The secondary and tertiary levels present greater availability of dense technology but not more complex technology. The distorted view held by people often leads them to seek care in medium or high complexity services instead of first seeking care in a PHC unit. ${ }^{3}$ Hence, there is a need to redeem PHC as the coordinator of care and main entrance door to the healthcare network, valuing not only increased coverage, but also promoting strategies to improve the quality of care delivery. It is also necessary to strengthen strategies to disseminate information to the population regarding how the healthcare network functions, the roles of each component of the network, and criteria that should be used when deciding whether one should seek out a PHC unit or UPA.

Some alternatives to curb the increased number of consultations provided in emergency services are being implemented by the British National Health Service, not only to decrease frequent lines but also to contain costs. A review study shows that, together with reinforcement of PHC services in order to expand access, new ways to provide emergency services are being implemented, in addition to traditional units. Telephone support services, home care provided in urgent situations, telehealth technology, increased legal duties for nurses, improved hospital admission flow, establishment of goals for urgent services, and the implementation of elderly-specific services, are reported. ${ }^{21}$

Studies using secondary databases and consolidated reports present limitations. This study used reports generated by the information system used by the city, thus we could only generate, account for, and analyze data recorded by those working in the UPAs and, as data are continually fed by different workers in a service with a high level of demand of a spontaneous nature, there may be underreporting.
Additionally, these data refer to a specific period of time and do not represent a historical series or longitudinal analysis. Due to limitations inherent to the city's information system and in the way its reports are produced, we could not access further data that could contribute to understanding of the object under study.

Further studies are necessary to more deeply identify why patients opt for UPAs instead of PHC units, which users should have as reference of service, how the flow of care within the healthcare network based on access to emergency services can be established and how the implementation of UPAs impact the health system.

\section{CONCLUSION}

This study enabled characterizing the demand of patients and type of care provided in 2013 in the UPAs located in Florianópolis, SC, Brazil in 2013.

In regard to the demand of patients for UPAs, we verified that most originated from the same health district in which the UPA is located, so that it is clear there is a search for the service that is nearest to people's homes. A total of $96.31 \%$ of the users cared for by UPA A and $93.88 \%$ cared for by UPA B were from Florianópolis.

This study shows that the main reasons patients seek UPAs are not properly characterized as urgent situations or emergencies; that is, their conditions were either classified as intercurrences or were conditions requiring outpatient care. Most of these cases could be taken care of and resolved in a PHC unit, showing there is a deviation from UPAs' real mission.

This study reinforces the need to strengthen PHC services as the first option to enter the healthcare system and also to put into effect health education strategies to clarify the responsibilities and roles of each component in the network.

\section{REFERENCES}

1. Mendes EV. As redes de atenção à saúde. Ciênc Saúde Coletiva [Internet]. 2010 [cited 2015 May 30]; 15(5):2297-2305. Available from: http:/ / www.scielo. $\mathrm{br} / \mathrm{pdf} / \mathrm{csc} / \mathrm{v} 15 \mathrm{n} 5 / \mathrm{v} 15 \mathrm{n} 5 \mathrm{a} 05 . \mathrm{pdf}$

2. Ministério da Saúde (BR). Política Nacional de Atenção às Urgências: Série E. Legislação de Saúde,

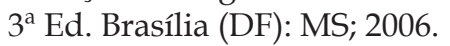

3. Ministério da Saúde (BR). Portaria n. 1.600 de 7 de julho de 2011: Reformula a Política Nacional de Atenção às Urgências e institui a Rede de Atenção às Urgências no Sistema Único de Saúde (SUS). Brasília (DF): MS; 2011. 
4. Ministério da Saúde (BR). Portaria n. 2048 de 05 de novembro de 2002: Regulamento técnico dos sistemas estaduais de urgência e emergência. Brasília(DF): MS; 2002.

5. Ministério da Saúde (BR). Portaria n. 104, de 15 de janeiro de 2014: Altera a Portaria n. 342/GM/MS, de 4 março de 2013, que redefine as diretrizes para implantação do Componente Unidade de Pronto Atendimento (UPA 24h) e do conjunto de serviços de urgência 24 horas não hospitalares da Rede de Atenção às Urgências e Emergências (RUE), em conformidade com a Política Nacional de Atenção às Urgências, e dispõe sobre incentivo financeiro de investimento para novas UPA 24h (UPA Nova) e UPA 24h ampliadas (UPA Ampliada) e respectivo incentivo financeiro de custeio mensal. Brasília (DF): MS; 2014.

6. Siqueira ILCP. Qualidade em serviço de emergência. In: Sallum AMC, Paranhos WY. O enfermeiro e as situações de emergência. São Paulo (SP): Atheneu; 2010. p.25-34.

7. Sallum AMC. Estrutura organizacional de um serviço de emergência. In: Sallum AMC, Paranhos WY. O enfermeiro e as situações de emergência. São Paulo (SP): Atheneu; 2010. p.15-24.

8. Instituto Brasileiro de Geografia e Estatística (IBGE). Contagem Populacional de Florianópolis, SC 2013 [cited 2015 May 30]. Available from: ftp:/ / ftp.ibge.gov. br/Estimativas_de_Populacao/Estimativas_2013/ estimativa_2013_dou.pdf

9. World Health Organization. The World Health Report 2008 - primary Health Care (Now More Than Ever). Geneve (CH): WHO; 2008.

10. Ministério da Saúde (BR). Política Nacional de Atenção Básica: Série E. Legislação de Saúde. Brasília (DF): MS; 2012.

11. Ministério da Saúde (BR). Portaria n. 1820 de 13 de agosto de 2009: Dispõe sobre os direitos e deveres dos usuários da saúde. Brasília (DF): MS; 2009.

12. Booker MJ, Shaw AR, Purdy S. Why do patients with 'primary care sensitive' problems access ambulance services? A systematic mapping review of the literature. BMJ Open. 2015 May 19; 5(5):e007726.

13. Secretaria municipal de saúde de Florianópolis. Classificação de risco. Publicado em 2012.
Florianópolis: SMS; 2012 [cited 2015 May 30]. Available from: http://www.pmf.sc.gov.br/ noticias $/$ ? pagina $=$ notpagina\&noti $=5113$

14. Wexler R, Hefner JL, Sieck C, Taylor CA, Lehman J, Panchal AR, Aldrich A, McAlearney AS. Connecting Emergency Department Patients to Primary Care. J Am Board Fam Med. 2015 Nov-Dec; 28(6):722-32.

15. National Health Service. England. High quality care for all, now and for future generations: transforming urgent and emergency care services in England. The evidence base from the urgent and emergency care review. 2013 [cited 2015 May 30]. Available from: http:/ / www.england.nhs.uk/wp-content/ uploads/2013/06/urg-emerg-care-ev-bse.pdf

16. Gomide MFS, Pinto IC, Figueiredo LAD. Acessibilidade e demanda em uma Unidade de Pronto Atendimento: perspectiva do usuário. Acta Paul Enferm [Internet]. 2012 [cited 2015 Jun 25]; 25(2). Available from: http:/ / dx.doi.org/10.1590/S0103-21002012000900004

17. Garlet ER, Lima MADS, Santos JLG, Marques GQ. Organização do trabalho de uma equipe de saúde no atendimento ao usuário em situação de urgência e emergência. Texto Contexto Enfermagem. 2009 AbrJun; 18(2):266-72.

18. Ministério da Saúde (BR). Acolhimento à demanda espontânea. Cadernos de atenção básica, n. 28, v 1, 62 p. Brasília (DF): MS; 2013.

19. Marshall EG, Clarke B, Burge F, Varatharasan N, Archibald G, Andrew MK. Improving continuity of care reduces emergency department visits by longterm care residents. J Am Board Fam Med. 2016 MarApr; 29(2):201-8.

20. Marques GQ, Lima MADS. Demandas de usuários a um serviço de pronto atendimento e seu acolhimento ao sistema de saúde. Rev Latino-Am Enfermagem [Internet]. 2007 [cited 2015 Jun 25]; 15(1). Available from: http://dx.doi.org/10.1590/S010411692007000100003

21. Mason S, Mountain G, Turner J, Arain M, Revue E, Weber EJ. Innovations to reduce demand and crowding in emergency care: a review study. Scand J Trauma Resusc Emerg Med. 2014 Sep 11; 22:55. 